\title{
A Study of Weeds as Potential Inoculum Sources for a Tomato-Infecting Begomovirus in Central Brazil
}

\author{
S. S. Barreto, M. Hallwass, O. M. Aquino, and A. K. Inoue-Nagata
}

First author: Department of Phytopathology, University of Brasilia, CEP 70910-900, Brasilia, DF, Brazil; and second, third, and fourth authors: Embrapa Vegetables, Cx. Postal 218, CEP 70359-970, Brasilia, DF, Brazil.

Accepted for publication 4 January 2013.

\section{ABSTRACT}

Barreto, S. S., Hallwass, M., Aquino, O. M., and Inoue-Nagata, A. K. 2013. A study of weeds as potential inoculum sources for a tomatoinfecting begomovirus in central Brazil. Phytopathology 103:436-444.

Tomato severe rugose virus (ToSRV) is the most important begomovirus species in Brazilian tomato production. Many weeds are associated with tomato, and some are hosts of begomoviruses. Only one species of weed, Nicandra physaloides, has been found to be infected with ToSRV. In this study, four weed species were investigated for their capacity to be infected by ToSRV and serve as a potential source of inoculum for tomato. Begomoviruses from naturally infected Crotalaria spp., Euphorbia heterophylla, $N$. physaloides, and Sida spp. were successfully transferred to tomato plants by biolistic inoculation. ToSRV was the major virus transferred to tomato. In contrast, other begomoviruses were transferred to weeds, such as Sida micrantha mosaic virus and Euphorbia yellow mosaic virus. Furthermore, a new strain of Sida micrantha mosaic virus is reported. We also confirmed that Crotalaria spp., E. heterophylla, and Sida spp. are infected with ToSRV but at low viral titers and in mixed infections with weed-infecting begomoviruses. Thus, it was demonstrated that weeds are potential sources of ToSRV for tomato in central Brazil.

Additional keywords: geminivirus.
Begomoviruses are viruses with a genome of circular singlestranded (ss)DNA, with one (monopartite) or two (bipartite, DNA-A and DNA-B) components. They infect many important crops worldwide and cause severe diseases $(21,41,43)$. They are also able to infect a variety of weed species present in the field, which can act as an inoculum source for crops $(6,40)$. Furthermore, weed plants are usually hosts of Bemisia tabaci, the whitefly vector of begomoviruses.

In Brazil, begomovirus diseases have been reported since the 1930s (12). Begomoviruses have become particularly important in dry bean (15). In tomato plants, the occurrence of serious outbreaks of begomovirus diseases started to be reported beginning in the 1990s, and these outbreaks have been attributed to the introduction and spread of the B biotype of B. tabaci $(27,46)$. This insect is known to readily colonize tomato plants, be extremely polyphagous, and have a higher fecundity than the A biotype (9). It is believed that these characteristics resulted in the displacement of the A biotype, the former biotype in Brazil, by the more aggressive B biotype (27,39). Many weed species have been reported as natural hosts of begomoviruses, especially those belonging to the families Malvaceae, Euphorbiaceae, Fabaceae, Caparaceae, and Sterculiaceae $(4,49)$. In Brazil, begomoviruses have been reported in weeds since the 1950s $(14,16,17)$, and a great diversity of begomovirus species have been characterized from weeds in recent decades $(2,4,10,35)$. When infected, most weed species shows the typical symptoms of a begomovirus infection, such as yellow mosaic, leaf distortion, and stunting. In the central part of Brazil, the following weeds (with or without symptoms) are commonly found in or around tomato fields:

Corresponding author: A. K. Inoue-Nagata; E-mail address: alice.nagata@embrapa.br

* The $e$-Xtra logo stands for "electronic extra" and indicates that the online version contains three supplemental figures.

http://dx.doi.org/10.1094/PHYTO-07-12-0174-R

(C) 2013 The American Phytopathological Society
Crotalaria spp., Euphorbia heterophylla, Nicandra physaloides, and Sida spp.

The introduction and dispersal of begomoviruses in a field occurs through the action of whiteflies that feed on nearby virus sources (13). There is some evidence that tomato-infecting begomoviruses are present in naturally infected weeds and that these viruses can be transmitted from weeds to tomato plants by whiteflies and grafting $(3,45)$. It has also been speculated that weeds can be reservoirs of tomato-infecting begomoviruses in the absence of tomato plants in the field, and that begomoviruses are transferred from weeds to tomato and vice-versa.

Although several begomoviruses have been reported infecting weeds in Brazil $(10,23,35,52)$, there is only one report of a natural infection of a weed infected with a tomato-infecting begomovirus: Tomato severe rugose virus (ToSRV) infecting N. physaloides (5). ToSRV is one of the predominant begomoviruses infecting tomato in central Brazil (24). The aim of this study was to determine if other weed species, as well as $N$. physaloides, can serve as a source of tomato-infecting begomoviruses.

\section{MATERIALS AND METHODS}

Sample collection and begomovirus detection. One leaf sample was collected from each of 27 weeds belonging to six genera that were in (or next to) tomato fields in central Brazil (the Federal District and Goiás State) (Table 1; Supplemental Figure 1) between 2005 and 2009. Most of these plants had begomovirus symptoms, including yellow mosaic, leaf distortion, and stunting. Total DNA from $50 \mathrm{mg}$ of leaf tissue of each sample was extracted (20) and stored at $-20^{\circ} \mathrm{C}$ until use. Detection of begomovirus DNA-A component was accomplished by polymerase chain reaction (PCR) using the universal primer pair PAL1v1978/ PAR1c496 (47). PCR products were analyzed by electrophoresis in $1.2 \%$ agarose gels stained with ethidium bromide.

Species-specific PCR. PCR was carried out with the total DNA extracts described above or with these extracts after amplification by rolling circle amplification (RCA) using phi-29 DNA poly- 
merase (New England Biolabs, Ipswich, MA). Specific primers were used for amplification of part of the genome of ToSRV, Euphorbia yellow mosaic virus (EuYMV) and Sida micrantha mosaic virus (SiMMV). Two pairs of ToSRV-specific primers were used: (i) ToSRV1f forward primer (5'-AAGGCGACG TCTTTGGAAGG-3') and ToSRV2r reverse primer (5'-CTCAGC GGCCTTGTTATATTT-3') for the amplification of a 820-bp DNA-A fragment representing the AV1, AC2, AC3, and part of $\mathrm{AC} 1$ open reading frames (ORFs) (25) and (ii) ToSB1450F forward primer (5'-GGGTCTAATGTGCCTGTAC-3') and ToSB1880R reverse primer (5'-CACTACTTTTCGTCGTCG-3') for the amplification of a 430-bp DNA-B fragment from the BC1 ORF. EuYMV primers were directed at the DNA-A component: EuA170F forward primer (5'-AAAGTAATTGACATTATTCGAT ATC-3') and EuA1084R reverse primer (5'-RAATTGGGTG TCGTCGGTC-3') for the amplification of a 914-bp fragment representing the AV1 ORF and part of the intergenic region and AC3 ORF. For amplification of SiMMV, the SimA1500F forward primer (5'-GGCAATCCTGTGTCTCGGTT-3') and SimA2114R reverse primer (5'-GGGAGAAGTTACCGGAAAAG-3') were used. These primers direct the amplification of a DNA-A fragment of $614 \mathrm{bp}$ from the AC1 ORF. All PCR reactions were performed with an annealing temperature of $62^{\circ} \mathrm{C}$.

Biolistic inoculation of begomoviruses in test plants. The circular viral DNA from 27 weed samples was amplified by RCA. In all, $\approx 500$ ng of RCA-amplified viral circular DNA from each sample were used for inoculation into eight tomato 'Viradoro' seedlings by biolistic (42). Inoculated seedlings were sprayed with Imidacloprid and maintained within insect-proof cages in a greenhouse until symptom development and total DNA extraction. All the tests were done in an insect-proof greenhouse with an antechamber; the plants were frequently sprayed with insecticides (changing the active ingredient every 3 weeks); healthy plants were distributed alongside the inoculated plants and monitored by
PCR; and yellow sticky traps were used to assure absence of whiteflies during the experiments. To confirm the infection, total DNA extracted from each plant 20 to 30 days postinoculation (dpi) was used for PCR with universal and specific primers.

From 18 samples containing begomoviruses able to infect tomato plants (Table 2), 1 sample each of the four most commonly found species associated with tomato production fields were selected for a detailed analysis of their abilities to host a tomatoinfecting begomovirus. These were referred to as selected original samples (SOSs) number 768 (Crotalaria sp.), number 780 (Sida sp.), number 1646 ( N. physaloides), and number 3539 (E. heterophylla). SOSs were used for a second round of biolistic inoculation into eight tomato Viradoro seedlings and into eight weed plants of the same species or a relative (plants in the same genus when the species was not identified). These inoculations were repeated in three independent experiments to confirm the ability of these begomoviruses to infect both hosts. For the sample from $N$. physaloides (SOS 1646), only four tomato and four N. physaloides plants were inoculated, because a high rate of infected plants was obtained in the first round of inoculations.

RCA-restriction fragment length polymorphism of viral DNA from infected plants. The begomoviruses present in the infected plants were analyzed preliminarily using RCA-restriction fragment length polymorphism RFLP analysis (30). RCA-amplified viral circular DNA was digested with the $M s p I$ restriction enzyme (New England Biolabs). Digestions were performed according to the manufacturer's instructions using $1.0 \mu \mathrm{l}$ of RCAamplified viral DNA. The digested DNA was separated by electrophoresis in $1.2 \%$ agarose gels and stained with ethidium bromide.

Cloning and sequencing of begomoviruses. The DNA-A component of begomoviruses present in the four SOSs and the inoculated plant samples with SOSs were cloned and sequenced. For the cloning of viral DNA, total DNA was subjected to RCA,

TABLE 1. Detection of begomoviruses by polymerase chain reaction (PCR) with universal and specific primers from tomato plants biolistically inoculated with rolling circle amplification-amplified viral DNA from weed samples collected in central Brazil

\begin{tabular}{|c|c|c|c|c|}
\hline \multirow[b]{2}{*}{ Collected plants } & \multirow[b]{2}{*}{ Number of samples ${ }^{\mathrm{a}}$} & \multicolumn{2}{|c|}{ Detection of begomovirus by PCR (infected/inoculated) ${ }^{b}$} & \multirow[b]{2}{*}{ Number of infected samples ${ }^{\mathrm{e}}$} \\
\hline & & Universal primerc $^{\mathrm{c}}$ & ToSRV DNA-A & \\
\hline Crotalaria sp. & 1 & $2 / 8$ & $2 / 2$ & 1 \\
\hline Euphorbia heterophylla & 17 & $37 / 136$ & $29 / 37$ & 12 \\
\hline Nicandra physaloides & 3 & $10 / 24$ & $9 / 10$ & 2 \\
\hline Sida spp. & 2 & $5 / 16$ & $4 / 5$ & 2 \\
\hline Solanum americanum & 2 & $2 / 16$ & $0 / 2$ & 0 \\
\hline
\end{tabular}

a Number of samples used to inoculate tomato plants. Eight tomato seedlings were inoculated with each weed sample.

${ }^{b}$ Universal and specific PCR reactions with tomato samples were performed using total DNA (number of infected tomato plants/number of inoculated tomato plants).

c PCR with universal primer pair for begomovirus.

${ }^{\mathrm{d}}$ Specific PCR for Tomato severe rugose virus (ToSRV) DNA-A; primer pair ToSRV1f/ToSRV2r.

e Number of samples that gave rise to ToSRV-infected tomato.

TABLE 2. Detection of begomovirus from weed samples collected in central Brazil by polymerase chain reaction (PCR) with universal and specific primers using viral DNA in total DNA and rolling circle amplification (RCA)-amplified viral DNA

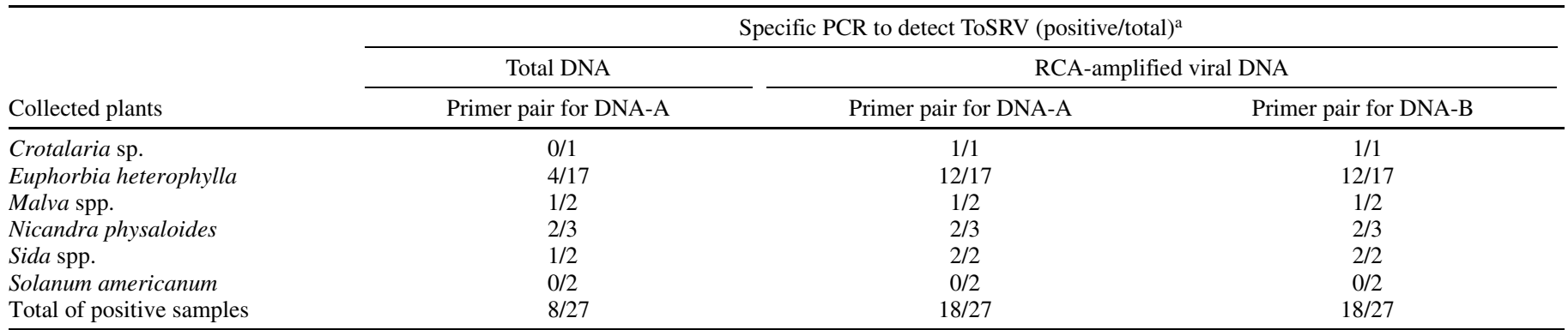

a Primers used for amplification of Tomato severe rugose virus (ToSRV): ToSRV1f/ToSRV2r to amplify fragment of DNA-A, and ToSB1450F/ToSB1880R to amplify fragment of DNA-B (number of PCR-positive samples/total number of samples). 
digested with restriction enzymes, and cloned, as described previously (34). The following restriction enzymes were used for monomerization of begomoviral genomes: EcoRI, ClaI, and HindIII for SOS 768 (Crotalaria sp.) and samples inoculated with DNA from this sample; BamHI and ClaI for SOS 780 (Sida sp.) and samples inoculated with DNA from this sample; ClaI and HindIII for SOS 1646 (N. physaloides) and samples inoculated with DNA from this sample; and HindIII for SOS 3539 (E. heterophylla) and samples inoculated with DNA from this sample. Restriction enzyme digested fragments were gel purified and ligated into appropriately linearized pBluescript SK+ (Stratagene, La Jolla, CA). At least one clone was obtained from each sample, and sequencing reactions were performed at Macrogen Inc. (Seoul, South Korea) using vector and internal primers.

The obtained sequences have been deposited in the GenBank database under the accession numbers JX415184-JX415202.

Sequence analysis. Sequences were assembled using the Staden Package program (53). The resulting final sequence was initially evaluated by BLASTn analysis (1) and compared with other begomovirus sequences by multiple alignment and pairwise comparison using ClustalV (32), which is included in the MegAlign program using the default parameters. Begomovirus taxonomy and nomenclature was accomplished according to the criteria established by the Geminivirus Study Group of the International Committee on Taxonomy of Viruses (ICTV) (8). The phylogenetic tree of DNA-A sequences was constructed in the Mega 5.10 program (54) using the neighbor-joining method with 3,000 bootstrap replications and the maximum composite likelihood model after multiple sequence alignment using ClustalW (55) with the following pairwise and multiple parameters: gap opening penalty $=15$, gap extension penalty $=6.66$.

\section{RESULTS}

Weed begomoviruses able to infect tomato plants. In total, 27 weed samples with typical symptoms of begomovirus infection were collected from six genera: Crotalaria spp., E. heterophylla, Malva spp., N. physaloides, Sida spp., and Solanum americanum. All of these samples tested positive for begomovirus infection by PCR with the universal begomovirus DNA-A component primer pair (data not shown). To test for the presence of tomato-infecting begomoviruses, samples were subjected to RCA and the resulting circular DNA was used for biolistic inoculation of tomato plants. In total, 216 plants were inoculated (8 for each sample) and 58 became infected based on development of symptoms and detection of begomovirus DNA by PCR with the universal DNA-A primer pair (Table 1). Between 20 and 30 dpi, most of the infected tomato plants developed vein clearing and interveinal chlorosis symptoms. After this period, these plants were eliminated. To test whether ToSRV isolates were transferred from these weed samples to tomato plants, the 58 begomovirus-infected tomato samples were tested for ToSRV by PCR with the specific primer pair for DNA-A component (ToSRV1f/ToSRV2r). Based on this test, 46 of the 58 plants were infected with ToSRV from DNA extracts of 18 weed samples (Table 1). This suggested that some of the plants can be infected with ToSRV and may act as a reservoir of the virus in the field. Furthermore, 38 samples from the 46 infected plants were derived from two weed species: E. heterophylla and $N$. physaloides. This may indicate that these two species are important reservoirs of ToSRV isolates.

Detection of ToSRV in weed samples by specific PCR. Because ToSRV was transferred from five of the six weed species (totaling 18 samples) to tomato plants (Table 1), it was expected that ToSRV was present in the original weed samples. Therefore, the original DNA extracts of the 27 samples were tested for ToSRV by PCR with the specific DNA-A component primer pair. ToSRV was detected in only eight samples of the weed species E. heterophylla, Malva spp., N. physaloides, and Sida spp. A sample from Crotalaria spp. tested negative for ToSRV in this test (Table 2). However, because tomato bombarded with DNA extracts (in which ToSRV was not detected by PCR) were infected with ToSRV (Table 1), we concluded that ToSRV was present in low titers in some extracts. Therefore, the original DNA extracts were subjected to RCA and then tested for ToSRV by PCR with the specific DNA-A component primer pair. ToSRV was detected in 18 samples, including in Crotalaria spp. (Table 2). The tomato plants inoculated with the DNA extracts of these 18 samples were infected with ToSRV (Table 1). For the $S$. americanum extract, ToSRV was not detected in the samples or the inoculated tomato plants, suggesting that another begomovirus species was present in these samples and that this virus can infect tomato (Table 2).

Furthermore, an additional PCR using RCA-amplified DNA was performed with the ToSRV-specific DNA-B component primer pair (ToSB-1450F/ToSB-1880R). Identical results were obtained for PCR reactions with the ToSRV-specific DNA-A and DNA-B component primer pairs (Table 2), confirming that ToSRV was present in these weeds. The number of samples in which ToSRV was detected was greater using RCA-amplified viral DNA than total DNA extracts.

Testing for confirmation that weeds can act as a source of begomoviruses in tomato. Of the 18 weed samples infected with ToSRV (Tables 1 and 2), 4 were selected for a more detailed study of their capacity to act as reservoirs of tomato-infecting begomoviruses and to reinfect the weed species (or a plant of the same genus when the species were not identified) from which the sample was originally obtained. One sample from each of the four most widespread weeds in the central region of Brazil was selected: SOS 768 (Crotalaria sp.), SOS 780 (Sida sp.), SOS 1646 (N. physaloides), and SOS 3539 (E. heterophylla). All four samples met the following criteria: (i) the sample contained begomoviruses able to infect tomato plants (Table 1), (ii) the sample was infected with ToSRV based on PCR using RCA-amplified viral DNA and ToSRV-specific DNA-A and DNA-B primers (Table 2), and (iii) the sequence of the PCR-amplified DNA-B fragment was $>92 \%$ identical with ToSRV DNA-B sequences (data not shown). Tomato and weed seedlings were biolistically inoculated with the RCA product of each of the four weed samples and evaluated by PCR. Following inoculation, the begomoviruses from the SOSs infected a small number of tomato and weed plants (Table 3). By 15 to 20 dpi, symptoms of mosaic were observed in infected E. heterophylla and Sida santaremnensis after inoculation with SOSs 3539 (E. heterophylla) and 780 (Sida sp.), respectively; and mosaic and strong leaf distortion symptoms were observed in $N$. physaloides after inoculation with SOS 1646 (N. physaloides). However, no symptoms were observed in infected Crotalaria juncea after inoculation with SOS 768 (Crotalaria sp.). Tomato plants inoculated with viral DNA from SOS 1646 ( N. physaloides) developed severe symptoms of mosaic and leaf deformation as early as $15 \mathrm{dpi}$ The symptoms in tomato inoculated with viral DNA from SOSs 768 (Crotalaria sp.), 780 (Sida sp.), and 3539 (E. heterophylla) were milder, with interveinal chlorosis and chlorotic spots by 30 dpi. By 40 to $60 \mathrm{dpi}$, the symptoms in these plants developed into mosaic and leaf deformation. Thus, it became clear that the four weed samples contained begomovirus isolates able to infect both tomato and weed plants but that the weeds might not be equal in their capacity to serve as reservoirs.

Analysis of begomoviruses by RCA-RFLP. Initially, the RCAamplified viral DNA from the 27 weed samples was analyzed by RCA-RFLP (Supplemental Figure 2). In total, 10 major RFLP profiles were observed. The sample from a Crotalaria sp. had a profile similar to one of the four profiles seen in E. heterophylla samples $(n=17)$. The three $N$. physaloides samples shared the same profile as one of the Malva spp. samples $(n=2)$, whereas different profiles were obtained in the two Sida spp. and two 
Solanum americanum samples. Therefore, it was concluded that at least 10 begomoviruses are most likely present in these samples, and that distinct weeds may be infected with the same virus, such as Crotalaria spp. and E. heterophylla, and Malva spp. and $N$. physaloides. To identify which begomoviruses were transferred from the SOSs to inoculated plants, RCA-amplified viral DNA samples from the SOSs and infected plants were analyzed by RFLP (Fig. 1). From the viral DNA present in the SOSs, three types of restriction digestion profiles were observed. This result indicates that the begomovirus from SOS 768 (Crotalaria sp.; lane 1) and SOS 3539 (E. heterophylla; lane 10) were similar (first type), whereas samples from SOS 780 (Sida sp.; lane 4, second type) and SOS 1646 (N. physaloides; lane 7, third type) were distinct. The summing of the estimated DNA fragment sizes indicated that each sample was apparently infected with a single begomovirus: $768(\Sigma=4.9 \mathrm{~kb}), 1646(\Sigma=5.4 \mathrm{~kb}), 3539(\Sigma=$ $4.9 \mathrm{~kb})$, and $780(\Sigma=5.0 \mathrm{~kb})$. Samples from inoculated plants were also analyzed. The begomovirus found in the $N$. physaloides SOS 1646 (lane 7) had a restriction digestion profile identical to that found in the inoculated $N$. physaloides sample (lane 8) as well as in a tomato plant inoculated with the extracts of this plant (lane 9; classified as the third type), indicating that the same virus was transferred to these plants. For the remaining three weedderived begomoviruses (SOS 768, SOS 780, and SOS 3539), the restriction profile clearly indicated that the viruses present or predominantly present (third type) in tomato (lanes 3, 6, and 12) were distinct from the predominant virus in the weed host (first and second types) (lanes 1, 4, and 10) but similar to the one found on $N$. physaloides 1646 (lane 7). However, the restriction enzyme digestion profile of the viruses present in each of the inoculated weed plants was identical to their respective SOSs (i.e., first and second types, lanes 2, 5, and 11). It was concluded that, except for $N$. physaloides SOS 1646, there were at least two begomoviruses in each of the weed samples.

Cloning and sequencing of begomoviruses present in the SOSs and the inoculated plants. The begomoviruses present in the SOSs and in the inoculated plants were identified by cloning and sequencing of at least one complete DNA-A component clone for each sample, for a total of 19 clones (Table 3). Identification of clones was according to the threshold of $89 \%$ nucleotide sequence identity of the full DNA-A genome for the same begomovirus species, established by the ICTV (8). Through pairwise comparison, seven sequences were 2,611 nucleotides (nt) and comparisons revealed that these had $\geq 95.9 \%$ sequence identity with the DNA-A sequence of EuYMV (accession number NC_012553.1); three sequences of $2,693 \mathrm{nt}$ shared $\geq 87.9 \%$ sequence identity with the DNA-A sequence of SiMMV (NC_005330.1), and nine sequences of $2,591 \mathrm{nt}$ shared $\geq 98.5 \%$ sequence identity with the DNA-A sequence of ToSRV (NC_009607.1). From the SOS group, EuYMV was isolated from SOS 768 (Crotalaria sp.) and SOS 3539 (E. heterophylla), SiMMV was isolated from SOS 780 (Sida sp.), and ToSRV was isolated from SOS 1646 (N. physaloides). From the inoculated weeds, EuYMV and ToSRV were obtained from one $C$. juncea plant inoculated with SOS 768 (Crotalaria sp.). Only SiMMV was isolated from Sida santaremnensis inoculated with SOS 780 (Sida sp.). EuYMV was isolated from E. heterophylla inoculated with SOS 3539 (E. heterophylla). ToSRV was isolated from $N$. physaloides after inoculation with SOS 1646 ( $N$. physaloides). From the tomato plants inoculated with SOS 768, EuYMV and ToSRV were isolated. Only ToSRV clones were obtained from tomato plants inoculated with SOSs 780, 1646, and 3539 (Table 3).

The restriction enzyme digestion profiles of the begomovirus in the SOSs and those transferred to inoculated plants were compared with the restriction profiles of the samples illustrated in Figure 1. To confirm the correlation between the restriction profiles and the three species isolated, the sequences from each species were subjected to in silico MspI restriction (56). There was a perfect match between the restriction profile and the in silico MspI digestion (data not shown). EuYMV sequences were correlated with the first type profile (Fig. 1, lanes 1, 2, 10, and 11). SiMMV sequences were correlated with the second type (Fig. 1, lanes 4 and 5). ToSRV sequences were correlated with the third type (Fig. 1, lanes 3, 6, 7, 8, 9, and 12). In samples from $C$. juncea (Fig. 1, lane 2) and tomato (Fig. 1, lane 3) inoculated with SOS 768, both ToSRV and EuYMV clones were obtained from a single plant (Table 3 ). The restriction profile predominant in $C$. juncea corresponded to the first type (assigned to EuYMV), while the tomato plant samples corresponded more frequently to the third type (assigned to ToSRV). This result suggests that one species predominates over the other in the plant but both could be cloned from co-infected plants.

Sequence analysis. Pairwise sequence comparisons were conducted with ClustalV. The seven EuYMV DNA-A sequences share $>97.6 \%$ nucleotide identity among themselves and $95.9 \%$ to $96.8 \%$ identity with the reference sequence (44) of EuYMV (NC_012553). The nine ToSRV sequences share $>98.7 \%$ nucleotide identity among themselves and 98.5 to $99.0 \%$ identity with ToSRV (NC_009607). The three SiMMV sequences share $>98.8 \%$ sequence identity with each other and 87.9 to $88.7 \%$ with

TABLE 3. Detection by polymerase chain reaction (PCR) of begomovirus transmitted by biolistic inoculation from selected original samples (SOSs) in tomato plants and weeds, and begomovirus clones obtained from SOSs and from one inoculated plant of each plant species

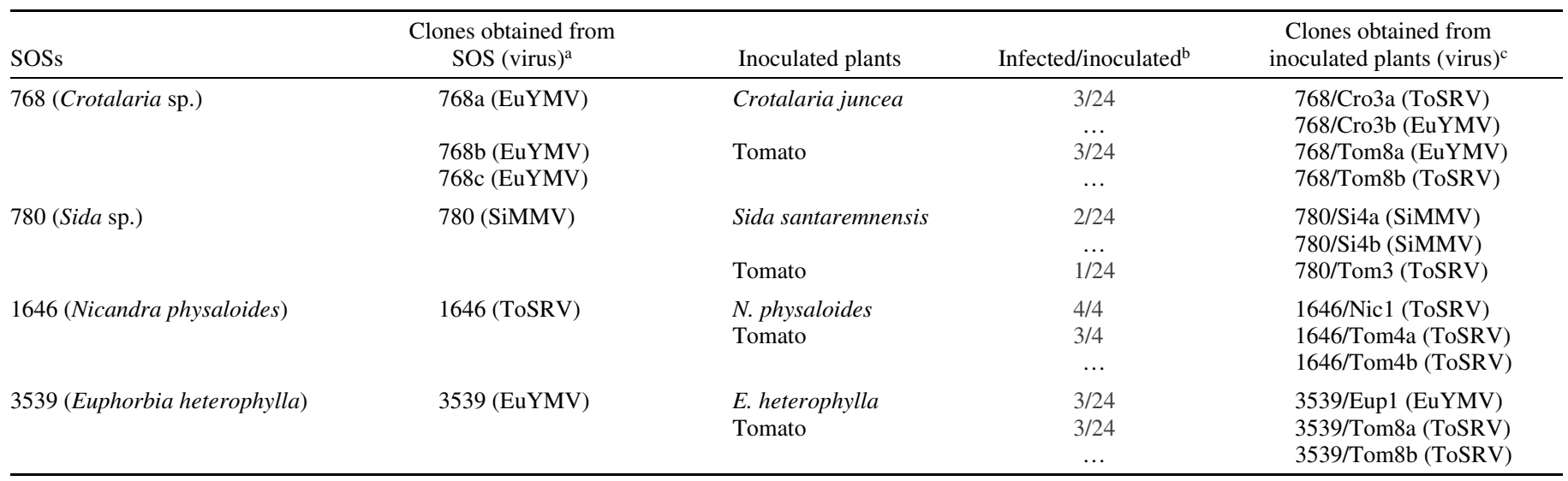

${ }^{a}$ EuYMV = Euphorbia yellow mosaic virus, SiMMV = Sida micrantha mosaic virus, and ToSRV = Tomato severe rugose virus.

${ }^{b}$ Number of infected plants/number of inoculated plants. The infection was analyzed by PCR with the universal primer pair for begomovirus PAL1v1978/PAR1c496.

${ }^{c}$ One infected plant was selected for begomovirus DNA-A cloning from each inoculation: 768/Cro3, 768/Tom8, 780/Si4, 780/Tom3, 1646/Nic1, 1646/Tom4, 3539/Eup1, and 3539/Tom8. 
SiMMV (NC_005330). Although these isolates share $<89 \%$ sequence identity with other SiMMV isolates, they were classified as SiMMV isolates according to the guidelines of ICTV regarding closely related sequences. The EuYMV and ToSRV isolates were identified as variants of previously reported species, whereas the SiMMV isolates were identified as a new strain of SiMMV, according to the criteria of ICTV, which established a threshold of $94 \%$ sequence identity for strain differentiation in begomoviruses (8).

All cloned DNA-A genomes have the typical organization of New World bipartite begomoviruses, with one ORF encoding for the coat protein gene on the virion strand and four ORFs encoding $\mathrm{AC} 4$, the replication-associated protein, the trans-activating protein, and the replication enhancer protein genes on the complementary strand. The intergenic region containing the origin of replication $(\approx 300 \mathrm{nt})$ was also identified.

A phylogenetic tree was constructed using all of the sequences determined here and those available in public databases, for a total of 80 sequences. Tomato leaf curl China virus sequence was used as the outgroup. For simplification, only three clusters are illustrated in Supplemental Figure 3. The first cluster contained all ToSRV sequences, including those isolated from SOS 1646 and from the following inoculated plants: $N$. physaloides (1646/Nic1), C. juncea (768/Cro3a), and tomato (768/Tom8b, 780/Tom3, 1646/Tom4a, 1646/Tom4b, 3539/Tom8a, and 3539/ Tom8b). This result suggests that the ToSRV isolates present in the weed samples or in the tomato samples are essentially similar and cluster tightly together. In the second cluster, the new SiMMV isolates from SOS 780 and inoculated S. santaremnensis samples (780/Si4a and 780/Si4b) were grouped with all other SiMMV sequences; however, the new sequences were separated in a strongly supported subgroup. This result is due to the lower identity of nucleotide sequence between SiMMV present in sample 780 and other SiMMV sequences reported to date. All new EuYMV sequences obtained from SOS 768 (768a, 768b, and

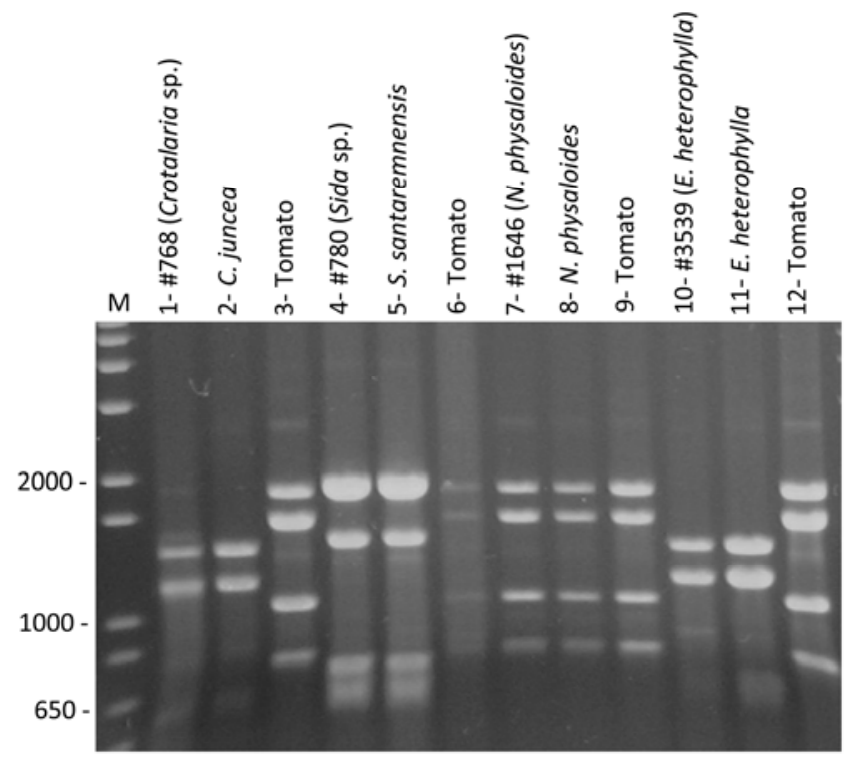

Fig. 1. Rolling circle amplification-restriction fragment length polymorphism (RCA-RFLP) analysis of amplified viral DNA digested with MspI using samples derived from selected original sample (SOS) number 768 (Crotalaria sp.): lane 1, original; lane 2, after inoculation to Crotalaria juncea; and lane 3, after inoculation to tomato; SOS 780 (Sida sp.): lane 4, original; lane 5, after inoculation to Sida santaremnensis; and lane 6, after inoculation to tomato; SOS 1646 (Nicandra physaloides): lane 7, original; lane 8, after inoculation to $N$. physaloides; and lane 9, after inoculation to tomato; and SOS 3539 (Euphorbia heterophylla): lane 10, original; lane 11, after inoculation to E. heterophylla; and lane 12, after inoculation to tomato. Lane M: 1-kb Plus DNA ladder (Invitrogen, Carlsberg, CA). 768c), SOS 3539, and inoculated samples from $C$. juncea (768/Cro3b), E. heterophylla (3539/Eup1), and tomato (768/Tom8a) plants were clustered together with other EuYMV isolates. All isolates most likely share a common ancestor with euphorbiainfecting viruses from South and Central America.

Species-specific detection by PCR. As it became clear that more than one virus was transferred to the inoculated plants, PCR reactions with species-specific primers were used to confirm the presence of each virus in the original DNA extract, and inoculated weed and tomato plants. The PCR reaction was performed with the extracts that had been subjected to RCA and specific primers for EuYMV, SiMMV, and ToSRV, indicating that the SOSs 768, 780, 1646, and 3539 were all positive for the three viruses (Fig. $2 \mathrm{~A}$ to D). From the group of inoculated weeds, EuYMV and ToSRV were detected in $C$. juncea after inoculation with SOSs 768 (Fig. 2A). The three species were detected in S. santaremnensis and E. heterophylla after inoculation with SOS 780 (Fig. 2B) and SOS 3539 (Fig. 2D), respectively. Only ToSRV was detected in $N$. physaloides inoculated with 1646 (Fig. 2C). From the inoculated tomato plants, ToSRV was detected in all samples after inoculation with the four SOSs (Fig. 2A to D). In addition to ToSRV, EuYMV was detected in tomato plants inoculated with SOSs 768, 780, and 3539 (Fig. 2A, B, and D). SiMMV was detected in tomato plants inoculated with SOSs 780 and 3539 (Fig. 2B and D). No fragment was amplified from the three healthy tomato samples for each primer pair (Fig. 2E) used as negative controls. In all samples, co-infections with the three viruses occurred and one or more viruses were transferred to the inoculated plants.

\section{DISCUSSION}

Begomovirus diseases are a serious problem for many cultivated plants worldwide, especially in tropical and subtropical regions where vector populations appear to be high throughout the year. There is no doubt that older tomato plants are the most efficient virus inoculum reservoir for newly transplanted tomato. However, a variety of weed species have been reported to be hosts of crop-infecting begomoviruses. Some weeds are naturally infected with begomoviruses pathogenic to important crops $(5,6$, $36,40,48)$ but their importance as virus reservoir for the crops has still to be demonstrated.

In this report, begomoviruses from Crotalaria spp., E. heterophylla, N. physaloides, and Sida spp. weeds were successfully transmitted to tomato plants; in particular, the isolates of ToSRV, a tomato-infecting begomovirus in Brazil (24). By sequencing these begomoviruses, it was concluded that they belong to species and strains previously described in Brazil. An exception was the begomovirus present in Sida spp. and inoculated S. santaremnensis, because three isolates were classified as a new strain of SiMMV (SiMMV-BR:A2B2); the name SiMMV-Santaremnensis is suggested.

Co-infections of begomoviruses were detected and confirmed in weeds by inoculation tests, RCA-RFLP analysis, PCR, and sequencing. The estimated sum of the DNA fragment sizes after RCA-RFLP indicated the occurrence of a single begomovirus in these samples. However, the restriction digestion profiles of the SOSs were clearly distinct from those of tomato plants inoculated with these samples (except for 1646). This indicated that the virus with the highest titer in the weeds (Crotalaria spp., E. heterophylla, and Sida spp.) was not the virus preferentially replicated to tomato plants.

In nature, co-infections of begomoviruses are common in weeds and wild plants $(35,57)$. Based on this study, it is concluded that mixed infection of begomoviruses in weeds may be common, and that usual detection procedures such as PCR may not be sensitive enough to efficiently detect them. In an agricultural system, co-infections in weeds and their effects on 
disease epidemiology are poorly understood. Some studies have shown the importance of these plants as a site for recombination, competition, and selection $(28,57)$. The weed Solanum nigrum is frequently infected with Tomato yellow leaf curl virus (TYLCV) (and related viruses), and it was demonstrated that this species plays a role as a reservoir for virus recombination and increased diversity for tomato yellow leaf curl disease epidemics in Spain $(6,28)$.

Remarkably, upon inoculation of tomato with DNA extracts of various weeds, plants were infected with ToSRV; in the case of weeds inoculated with these extracts, $N$. physaloides was infected with ToSRV, $C$. juncea and E. heterophylla were infected with EuYMV, and a Sida sp. was infected with SiMMV. This confirmed that ToSRV can be present in weeds associated with to- mato, especially $N$. physaloides. The restriction digestion profiles perfectly correlated with virus identification by PCR and sequencing. The first type profile correlated with EuYMV isolates, while those of the second type correlated with SiMMV isolates and the third type correlated with ToSRV clones. In the samples of tomato and $C$. juncea infected with EuYMV and ToSRV (after inoculation with SOS 768), there was a predominance of one restriction profile over the other according to the host; in $C$. juncea, the restriction profile of EuYMV predominated over ToSRV whereas, in the tomato plants, the restriction profile of ToSRV was predominant over EuYMV. This result suggested that EuYMV has a better fitness for $C$. juncea, whereas ToSRV has a better fitness for tomato. It has been previously shown that begomoviruses that are less adapted to a host cause mild symp-
A

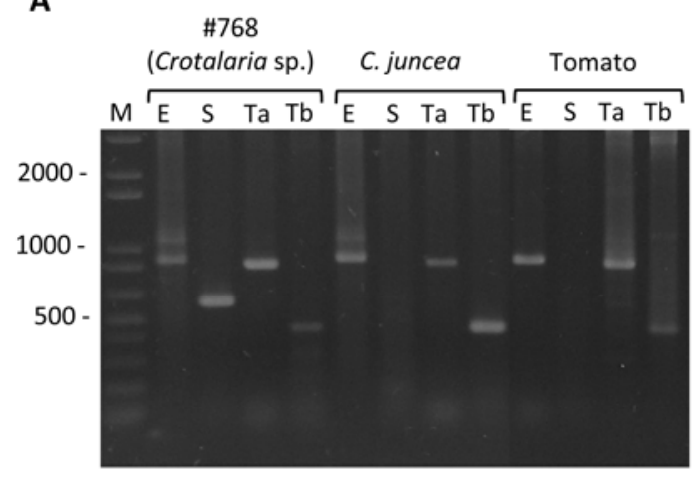

C

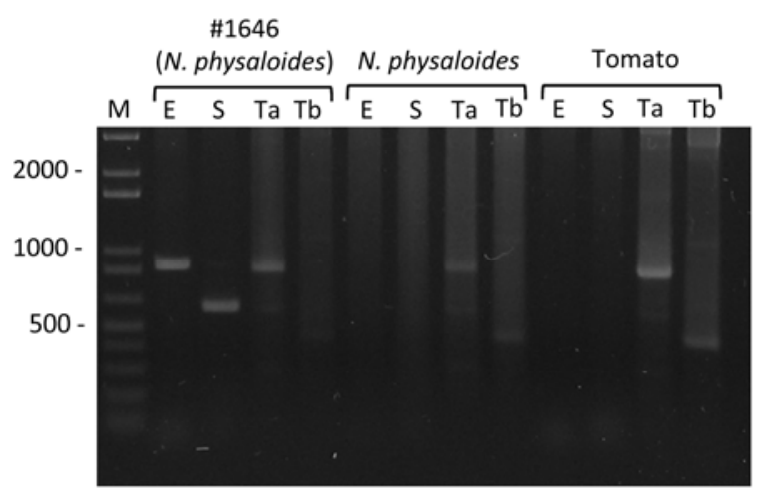

B

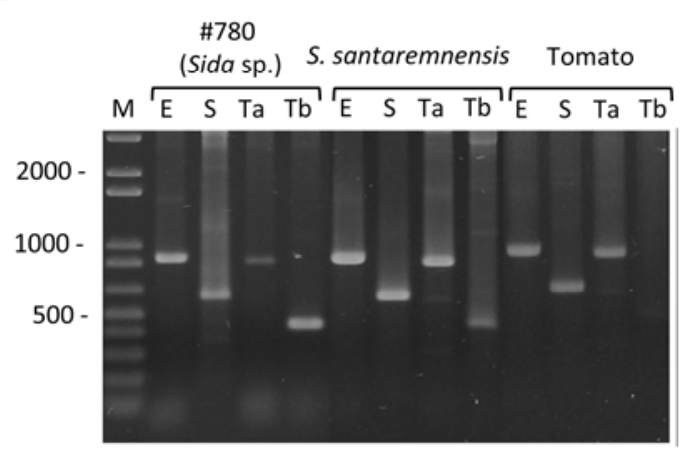

D

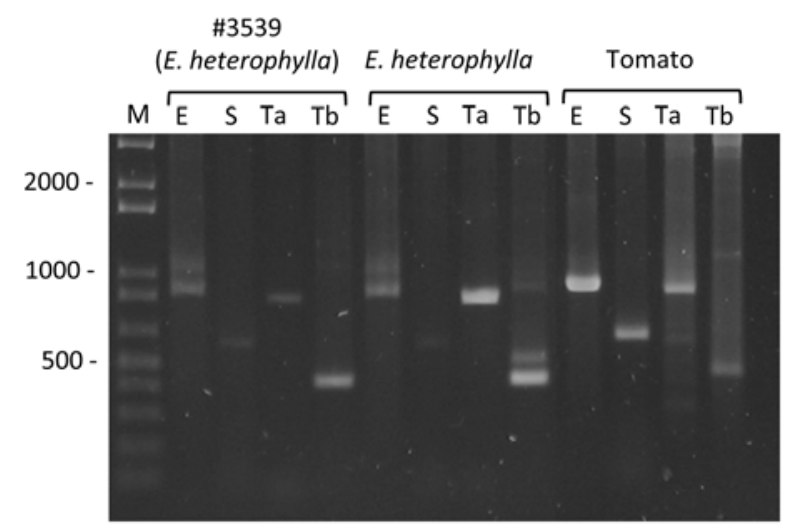

E

Negative control

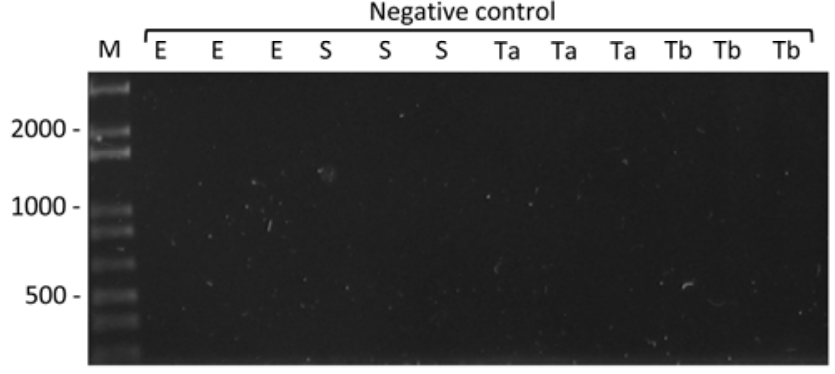

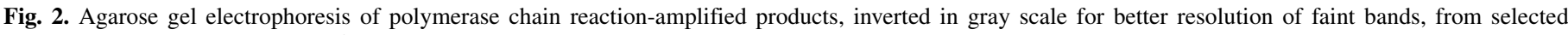

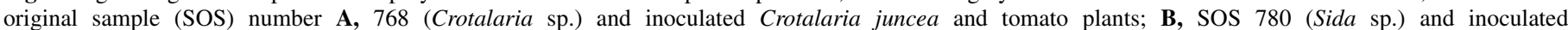

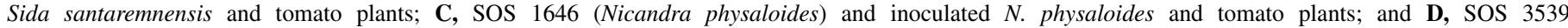

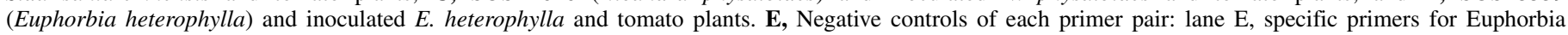

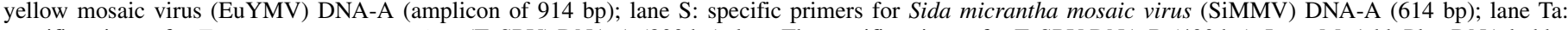

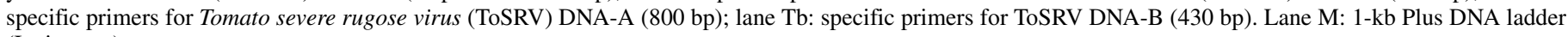
(Invitrogen). 
toms and accumulate at low levels (33). This would explain why a ToSRV-like genome profile is observed in tomato and a nonToSRV-like profile is observed in weeds (except $N$. physaloides). Therefore, the fittest begomovirus is at higher titers and, thus, is preferentially cloned, even though other begomoviruses are present. During competition among many viruses, the host seems to act as a filter.

The analysis of the RCA-RFLP profiles of the initial 27 weed samples confirmed that EuYMV seemed to predominate in Crotalaria spp. and E. heterophylla samples, and ToSRV in N. physaloides samples.

PCR carried out with species-specific primers demonstrated that the four SOSs (Crotalaria spp., E. heterophylla, N. physaloides, and Sida spp.) contained a mixture of isolates of different species, including $N$. physaloides plants that were apparently infected solely with ToSRV. However, the presence of some of the viruses in the sample was not revealed by a simple PCR, indicating that some of these were present at low titers. To detect these viruses, RCA had to be performed to enrich the circular DNA populations and, thus, enable their detection by PCR. In a similar situation, a normal PCR reaction was not sufficient to detect TYLCV in weeds from the Dominican Republic (48). In this case, the problem was solved by using a large quantity of DNA extract in the reaction. To avoid the addition of PCR inhibitors together with an increased amount of viral DNA (therefore elevating the risks of false positives), a prior RCA may be more efficient at detecting begomoviruses present at low titers in different hosts. Of the four species analyzed, N. physaloides was the only species previously reported as a natural host of ToSRV, and this virus was transmitted from these weeds to tomato by $B$. tabaci (5). In the present study, it was confirmed that $N$. physaloides is an excellent alternative host of ToSRV, which is able to infect tomato. Furthermore, the capacity to detect ToSRV from this weed and tomato by RCA-RFLP and PCR using viral DNA from total DNA extracts indicates that ToSRV is well adapted to both hosts. Therefore, the elimination of $N$. physaloides, which is a widespread weed in South America, is highly recommended to reduce ToSRV inoculum levels in the field.

Some begomoviruses are reported in the genus Crotalaria. $C$. juncea is associated with the leaf curl disease in India $(37,38,45)$, and the begomovirus species Papaya leaf curl virus (accession number GQ200446.1) and Sunn hemp leaf distortion virus (accession number NC_013019.1) were isolated (A. Das, unpublished data). In Brazil, fabaceous plants are usually infected with Bean golden mosaic virus (22) and, recently, four new species were reported in Macroptillium lathyroides (52). In this study, a Crotalaria sp. was found to be infected with EuYMV as well as with ToSRV isolates.

The disease known as euphorbia mosaic is characterized by strong yellow mosaic symptoms and is common in Brazil. A begomovirus from E. heterophylla was one of the first to be thoroughly studied in this country $(17,18)$. A similar disease was later described in Venezuela and Puerto Rico $(7,19)$ but the causal viruses were not fully identified. Later, isolates of Euphorbia mosaic virus were associated with a disease in Central America $(11,26,29,31)$. Another species, the Euphorbia mosaic Peru virus, was also found in this plant in Peru (50). Recently, in Brazil, a new euphorbia-infecting begomovirus was described, and the name EuYMV was proposed (23). Currently, all begomovirus isolates found in E. heterophylla plants in Brazil are classified as EuYMV isolates, with a low diversity among them. The results of this study provide further evidence for the role of EuYMV in the yellow mosaic disease in Brazil.

Sida plants were historically found with symptoms known as "infectious chlorosis of malvaceous plants" since the 1940s in Brazil (51). Similar diseases associated with distinct begomoviruses have been reported in other countries. Three species have been reported in Brazil thus far (SiMMV, Sida mottle virus, and Sida yellow mosaic virus) (8), and three additional species have been proposed $(10,57)$. In this study, a new strain of SiMMV was detected in Sida spp. in Brazil and the name SiMMV-Santaremnensis was suggested.

ToSRV isolates were present in naturally infected Crotalaria spp., E. heterophylla, Sida spp., and N. physaloides plants growing in close association to tomato fields. These isolates were below the limit of detection by PCR using viral DNA from total DNA extracts but were identified following biolistic inoculation and subsequent infection of tomato. Furthermore, ToSRV was preferentially transferred from these weeds to tomato plants by biolistic inoculation, a clear demonstration that ToSRV isolates are more fit in tomato plants than in other plants (except $N$. physaloides). In contrast, EuYMV preferentially infected $C$. juncea and E. heterophylla plants, and SiMMV preferentially infected Sida santaremnensis plants. Therefore, it seems that ToSRV is not well adapted to weed hosts. Nevertheless, these plants could be important ToSRV reservoirs because they are mostly perennial and widely distributed in Brazil. To fully address this issue, transmission tests with the vector $B$. tabaci are essential. This information is particularly important because there is a legislative measure, applied to some regions in Brazil, that mandates a 2-month period free of tomato production during the year. In such circumstances, the elimination of weeds that are really important sources for begomovirus-infecting tomato (and other tomato begomovirus sources) may be of extreme importance to guarantee the efficiency of this measure. In other countries, a similar measure is based in the whitefly host-free period to manage TYLCV in tomato crops. A study in the Dominican-Republic demonstrated that weeds can be a potential TYLCV reservoir during the whitefly host-free period and early in the tomato season; however, the beneficial effect of the host-free period did not require elimination of weed hosts (48), presumably because the virus was not effectively acquired from these low-titer hosts by the whitefly vector.

In this study, it was only possible to work with four species. The most important weeds were selected but there are others that should be considered in future investigations. The role of the widespread solanaceous weed Solanum americanum was not studied sufficiently, because the two samples did not contain ToSRV isolates confirmed by RCA-RFLP and PCR (Table 2). It is believed that this species is not an important reservoir of begomoviruses for tomato because this plant is rarely observed with symptoms, even in association with a heavily infected tomato field (unpublished observations).

The major goal of this study was to demonstrate the importance of weeds, in addition to $N$. physaloides, as a source of ToSRV in the field. We have shown evidence that Crotalaria spp., E. heterophylla, and Sida spp. may act as a source of ToSRV in the field but they are less efficient than $N$. physaloides and tomato plants. In this case, the presence of non-fit begomoviruses was detected if the population of ssDNA was previously enriched by RCA. Here, ToSRV was considered as a fitter virus in tomato and N. physaloides, EuYMV fitter in Crotalaria spp. and E. heterophylla, and SiMMV in Sida spp. Furthermore, we report the natural infection of Crotalaria spp., E. heterophylla, and Sida spp. with ToSRV, and also the infection of Crotalaria spp. with EuYMV. The ultimate importance of these weeds as ToSRV reservoirs, especially those with low viral titers, will depend on the efficiency with which they can be acquired and transmitted by the whitefly vector.

\section{ACKNOWLEDGMENTS}

This research was sponsored by $\mathrm{CNPq}$ and Embrapa. A. K. InoueNagata is a CNPq fellow. We thank L. F. Barbosa, H. J. Lourenço, and F. Aragão for technical assistance. 


\section{LITERATURE CITED}

1. Altschul, S. F., Madden, T. L., Schäffer, A. A., Zhang, J., Zhang, Z., Miller, W., and Lipman, D. J. 1997. Gapped BLAST and PSI-BLAST: A new generation of protein database search programs. Nucleic Acids Res. 25:3389-3402.

2. Ambrozevícius, L. P., Calegario, R. F., Fontes, E. P. B., Carvalho, M. G., and Zerbini, F. M. 2002. Genetic diversity of begomovirus infecting tomato and associated weeds in Southeastern Brazil. Fitopatol. Bras. 27:372-377.

3. Arnaud, L. S. E. P., Santos, C. D. G., Lima, J. A. A., and Feitosa, F. A. A. 2007. Predominância de begomovírus em tomateiros na região produtora da Ibiapaba, Ceará, e sua detecção natural em plantas daninhas. Fitopatol. Bras. 32:241-246.

4. Assunção, I. P., Listik, A. F., Barros, M. C. S., Amorin, E. P. R., Silva, S. J. C., O. Silva, I., Ramalho-Neto, C. E., and Lima, G. S. A. 2006. Diversidade genética de Begomovirus que infectam plantas invasoras na região nordeste. Planta Daninha 24:239-244.

5. Barbosa, J. C., Barreto, S. S., Inoue-Nagata, A. K., Reis, M. S., Firmino, A. C., Bergamin, A., and Rezende, J. A. M. 2009. Natural infection of Nicandra physaloides by Tomato severe rugose virus in Brazil. J. Gen. Plant Pathol. 75:440-443.

6. Bedford, I. D., Kelly, A., Banks, G. K., Briddon, R. W., Cenis, J. L., and Markham, P. G. 1998. Solanum nigrum: an indigenous weed reservoir for a tomato yellow leaf curl geminivirus in southern Spain. Eur. J. Plant Pathol. 104:221-222.

7. Bird, J., and Sanchez, Y. 1971. Whitefly-transmitted viruses in Puerto Rico. J. Agric. Univ. P.R. 55:461-467.

8. Brown, J. K., Fauquet, C. M., Briddon, R. W., Zerbini, M., Moriones, E., and Navas-Castillo, J. 2012. Geminiviridae. Pages 351-373 in: Virus Taxonomy: Classification and Nomenclature of Viruses: Ninth Rep. Int. Committee on Taxonomy of Viruses. A. M. Q. King, M. J. Adams, E. B. Carstens, and E. J. Lefkowitz, eds. Elsevier/Academic Press., San Diego, CA.

9. Brown, J. K., Frohlish, D. R., and Rosell, R. C. 1995. The sweetpotato or silverleaf whiteflies: biotypes of Bemisia tabaci or a species complex? Annu. Rev. Entomol. 40:511-534.

10. Castillo-Urquiza, G. P., Beserra, J. E., Jr., Bruckner, F. P., Lima, A. T., Varsani, A., Alfenas-Zerbini, P., and Murilo Zerbini, F. 2008. Six novel begomoviruses infecting tomato and associated weeds in Southeastern Brazil. Arch. Virol. 153:1985-1989.

11. Collins, A., Brown, J., Mujaddad Rehman, M., and Roye, M. 2009. Complete nucleotide sequence of an isolate of Euphorbia mosaic virus that infects Euphorbia heterophylla and Wissadula amplissima in Jamaica. Arch. Virol. 154:1859-1860.

12. Costa, A. S. 1937. Nota sobre o mosaico do algodoeiro. Rev. Agric. 12:453-470.

13. Costa, A. S. 1954. Identidade entre o mosaico comum do algodoeiro e a clorose indecciosa das malváceas. Bragantia 13:23-27.

14. Costa, A. S. 1955. Studies on Abutilon mosaic in Brazil. Phytopathol. Z. 24:97-112.

15. Costa, A. S. 1965. Three whitefly-transmitted virus diseases of beans in São Paulo, Brazil. Plant Prot. Bull. FAO 13:2-12.

16. Costa, A. S. 1976. Espécies suscetíveis ao mosaico dourado do feijoeiro que podem servir de reservatório do vírus. Fitopatol. Bras. 9:37.

17. Costa, A. S., and Bennet, C. W. 1950. Whitefly transmitted virus diseases of Euphorbia prunifolia Phytopathology 40:266-283.

18. Costa, A. S., and Carvalho, A. M. 1960. Comparative studies between the Abutilon and Euphorbia mosaic virus. Phytopathol. Z. 38:129-152.

19. Debrot, E., and Centeno, F. 1986. Ocurrencia del virus mosaico de las euforbiaceas infectando a Euphorbia heterophylla L. em Venezuela. Agron. Trop. 35:5-12.

20. Doyle, J. J., and Doyle, J. L. 1991. Isolation of plant DNA from fresh tissue. Focus 1:13-15.

21. Faria, J. C., Bezerra, I. C., Zerbini, F. M., Ribeiro, S. G., and Lima, M. F. 2000. Situação atual das geminiviroses no Brasil. Fitopatol. Bras. 25:125137.

22. Faria, J. C., and Maxwell, D. P. 1999. Variability in geminivirus isolates associated with Phaseolus spp. in Brazil. Phytopathology 89:262-268.

23. Fernandes, F. R., Albuquerque, L. C., Oliveira, C. L., Cruz, A. R. R., Rocha, W. B., Pereira, T. G., Naito, F. Y. B., Dias, N. d. M., Nagata, T., Faria, J. C., Zerbini, F. M., Aragão, F. J. L., and Inoue-Nagata, A. K. 2011. Molecular and biological characterization of a new Brazilian begomovirus, Euphorbia yellow mosaic virus (EuYMV), infecting Euphorbia heterophylla plants. Arch. Virol. 156:2063-2069.

24. Fernandes, F. R., de Albuquerque, L. C., de Britto Giordano, L., Boiteux, L. S., de Avila, A. C., and Inoue-Nagata, A. K. 2008. Diversity and prevalence of Brazilian bipartite begomovirus species associated to tomatoes. Virus Genes 36:251-258.

25. Fernandes, F. R., de Albuquerque, L. C., and Inoue-Nagata, A. K. 2010.
Development of a species-specific detection method for three Brazilian tomato begomoviruses. Trop. Plant Pathol. 35:43-47.

26. Fiallo-Olivé, E., Navas-Castillo, J., Moriones, E., and Martínez-Zubiaur, Y. 2012. Begomoviruses infecting weeds in Cuba: increased host range and a novel virus infecting Sida rhombifolia. Arch. Virol. 157:141146.

27. França, F. H., Vilas-Boas, G. L., and Castelo-Branco, M. 1996. Occurrence of Bemisia argentifolii Bellows \& Perring (Homoptera: Aleyrodidae) in the Federal District. An. Soc. Entomol. Brasil. 25:369-372.

28. Garcia-Andres, S., Monci, F., Navas-Castillo, J., and Moriones, E. 2006. Begomovirus genetic diversity in the native plant reservoir Solanum nigrum: Evidence for the presence of a new virus species of recombinant nature. Virology 350:433-442.

29. Gregorio-Jorge, J., Bernal-Alcocer, A., Banuelos-Hernandez, B., AlpucheSolis, A., Hernandez-Zepeda, C., Moreno-Valenzuela, O., Frias-Trevino, G., and Arguello-Astorga, G. 2010. Analysis of a new strain of Euphorbia mosaic virus with distinct replication specificity unveils a lineage of begomoviruses with short Rep sequences in the DNA-B intergenic region. Virol. J. 7:275.

30. Haible, D., Kober, S., and Jeske, H. 2006. Rolling circle amplification revolutionizes diagnosis and genomics of geminiviruses. J. Virol. Methods 135:9-16.

31. Hernandez-Zepeda, C., Idris, A. M., Carnevali, G., Brown, J. K., and Moreno-Valenzuela, O. A. 2007. Molecular characterization and experimental host range of Euphorbia mosaic virus-Yucatan Peninsula, a begomovirus species in the Squash leaf curl virus clade. Plant Pathol. 56:763-770.

32. Higgins, D. G., Bleasby, A. J., and Fuchs, R. 1992. CLUSTAL V: Improved software for multiple sequence alignment. Computer applications in the biosciences. CABIOS 8:189-191.

33. Hou, Y.-M., Paplomatas, E. J., and Gilbertson, R. L. 1998. Host adaptation and replication properties of two bipartite geminiviruses and their pseudorecombinants. Mol. Plant-Microbe Interact. 11:208-217.

34. Inoue-Nagata, A. K., Albuquerque, L. C., Rocha, W. B., and Nagata, T. 2004. A simple method for cloning the complete begomovirus genome using the bacteriophage phi29 DNA polymerase. J. Virol. Methods 116:209-211.

35. Jovel, J., Reski, G., Rothenstein, D., Ringel, M., Frischmuth, T., and Jeske, H. 2004. Sida micrantha mosaic is associated with a complex infection of begomoviruses different from Abutilon mosaic virus. Arch. Virol. 149:829-841.

36. Kashina, B. D., Mabagala, R. B., and Mpunami, A. A. 2003. First report of Ageratum conyzoides L. and Sida acuta Burm F. as new weed hosts of tomato yellow leaf curl Tanzania virus. Plant Prot. Sci. 39:18-22.

37. Khan, J. A., Siddiqui, M. K., and Singh, B. P. 2002. The natural occurrence of a begomovirus in sunn hemp (Crotalaria juncea) in India. Plant Pathol. Oxford 51:398.

38. Kumar, A., Kumar, J., Khan, Z. A., Yadav, N., Sinha, V., Bhatnagar, D., and Khan, J. A. 2010. Study of betasatellite molecule from leaf curl disease of sunn hemp (Crotalaria juncea) in India. Virus Genes 41:432440.

39. Lourenção, A. L., and Nagai, H. 1994. Surtos populacionais de Bemisia tabaci no estado de São Paulo. Bragantia 53:53-59.

40. McGovern, R. J., Polston, J. E., Danyluk, G. M., Hiebert, E., Abouzid, A. M., and Stansly, P. A. 1994. Identification of a natural weed host of tomato mottle geminivirus in Florida. Plant Dis. 78:1102-1106.

41. Morales, F. J., and Anderson, P. K. 2001. The emergence and dissemination of whitefly-transmitted geminiviruses in Latin America. Arch. Virol. 146:415-441.

42. Paplomatas, E. J., Patel, V. P., Hou, Y. M., Noueiry, A. O., and Gilbertson, R. L. 1994. Molecular characterization of a new sap-transmissible bipartite genome geminivirus infecting tomatoes in Mexico. Phytopathology $84: 1215-1224$

43. Polston, J. E., and Anderson, P. K. 1997. The emergence of whiteflytransmitted geminiviruses in tomato in the Western Hemisphere. Plant Dis. 81:1358-1369.

44. Pruitt, K., Brown, G., Tatusova, T., and Maglott, D. 2002. The Reference Sequence (RefSeq) Database. Chapter 18 in: The NCBI Handbook. J. McEntyre and J. Ostell, eds. NCBI-NLM, Rockville Pike, Bethesda, MD.

45. Raj, S. K., Singh, R., Pandey, S. K., and Singh, B. P. 2003. Association of a geminivirus with a leaf curl disease of sunn hemp (Crotalaria juncea) in India. Eur. J. Plant Pathol. 109:467-470.

46. Ribeiro, S. G., Ambrozevícius, L. P., De Avila, A. C., Bezerra, I. C., Calegario, R. F., Fernandes, J. J., Lima, M. F., Mello, R. N., Rocha, H., and Zerbini, F. M. 2003. Distribution and genetic diversity of tomatoinfecting geminiviruses in Brazil. Arch. Virol. 148:281-295.

47. Rojas, M. R., Gilbertson, R. L., Russell, D. R., and Maxwell, D. P. 1993. Use of degenerate primers in the polymerase chain reaction to detect whitefly-transmitted geminiviruses. Plant Dis. 77:340-347.

48. Salati, R., Nahkla, M. K., Rojas, M. R., Guzman, P., Jaquez, J., Maxwell, 
D. P., and Gilbertson, R. L. 2002. Tomato yellow leaf curl virus in the Dominican Republic: Characterization of an infectious clone, virus monitoring in whiteflies, and identification of reservoir hosts. Phytopathology 92:487-496.

49. Santos, C. D. G., Ávila, A. C. d., and Resende, R. d. O. 2003. Estudo da interação de um begomovírus isolado de tomateiro com a mosca branca. Fitopatol. Bras. 28:664-673.

50. Shepherd, D. N., Martin, D. P., Lefeuvre, P., Monjane, A. L., Owor, B. E., Rybicki, E. P., and Varsani, A. 2008. A protocol for the rapid isolation of full geminivirus genomes from dried plant tissue. J. Virol. Methods 149:97-102.

51. Silberschmidt, K. 1943. Estudos sobre a transmissão experimental da "clorose infecciosa" das malvaceas. Arq. Inst. Biol. São Paulo 14:105156.

52. Silva, S. J. C., Castillo-Urquiza, G. P., Hora-Júnior, B. T., Assunção, I. P., Lima, G. S. A., Pio-Ribeiro, G., Mizubuti, E. S. G., and Zerbini, F. M. 2011. Species diversity, phylogeny and genetic variability of begomovirus populations infecting leguminous weeds in northeastern Brazil. Plant Pathol. 61:457-467.

53. Staden, R. 1996. The staden sequence analysis package. Mol. Biotechnol. 5:233-241

54. Tamura, K., Peterson, D., Peterson, N., Stecher, G., Nei, M., and Kumar, S. 2007. MEGA4: Molecular Evolutionary Genetics Analysis (MEGA) software version 4.0. Mol. Biol. Evol. 24:1596-1599.

55. Thompson, J. D., Higgins, D. G., and Gibson, T. J. 1994. CLUSTAL_W: Improving the sensitivity of progressive multiple sequence alignment through sequence weighting, position-specific gap penalties and weight matrix choice. Nucleic Acids Res. 22:4673-4680.

56. Vincze, T., Posfai, J., and Roberts, R. J. 2003. NEBcutter: A program to cleave DNA with restriction enzymes. Nucleic Acids Res. 31:3688-3691.

57. Wyant, P. S., Sthromeier, S., Schafer, B., Krenz, B., Asssunção, I. P., Lima, G. S. A., and Jeske, H. 2012. Circular DNA genomics (circomics) exemplified for geminiviruses in bean crops and weeds of northeastern Brazil. Virol. J. 427:151-157. 